\title{
Investigating monetary policy dynamics in Nigeria: The role of private investment
}

\author{
Ilhan Bora $^{a^{*}}$, Dervis Kirikkaleli ${ }^{b}$, Joshua Dzankar Zoakac ${ }^{c}$, Festus Victor Bekunc and Daberechi \\ Chikezie Ekwueme ${ }^{\mathrm{c}}$
}

${ }^{a}$ Faculty of Business, Cyprus Science University, Kyrenia, Northern Cyprus, TR-10 Mersin, Turkey

${ }^{b}$ Department of Banking and Finance, Faculty of Economic and Administrative Science, European University of Lefke, Lefke, Northern Cyprus, TR-10 Mersin, Turkey

${ }^{c}$ Faculty of Business and Economics, Department of Economics, Famagusta, Eastern Mediterranean University, North Cyprus, via Mersin 10, Turkey

\begin{tabular}{l}
\hline C H R O N I C L E \\
\hline Article history: \\
Received: June 92019 \\
Received in revised format: July 9 \\
2019 \\
Accepted: July 24, 2019 \\
Available online: \\
July 26, 2019 \\
\hline Keywords: \\
Monetary policy \\
Investment portfolio \\
ARDL \\
Nigeria \\
\hline
\end{tabular}

\section{A B S T R A C T}

This paper explored the dynamics of monetary policy and its effect on private investment, using annual frequency data from 1981 to 2017 . The paper employed autoregressive distributive lags methodology to estimate the link between private investment and some selected monetary indicators. Empirical finding shows that broad money supply increases private investment in the long run for the study area. Interestingly, our study shows inverse relationship between exchange rate and private investment. These findings are insightful for policymakers for strategic policy mix construction. Consequently, the study recommends, among other things, proper coordination of monetary and fiscal policies, good macroeconomic policies, proper channeling of financial resources to the private sector and proper measures for controlling inflation.

(C) 2020 by the authors; licensee Growing Science, Canada

\section{Introduction}

In the past years, the economic setting that led the monetary policy earlier in 1986 was highly dominated by oil sector and the public sector was over reliant on other external sectors (Ajayi, 1978). To sustain good balance of payment and stability in price, the management of monetary policy depends on the direct monetary instruments which comprises of interest rate, exchange rate, credit ceiling and selective credit control. Brauning and Ivashina (2017) explained that when the monetary policy of US tightens, foreign funding condition was gotten by the global banks through fund transfer from their foreign offices. However, in the pursuit of monetary policy in Nigeria, there have been two basic regimes which are; before the period of 1986 structural adjustment program (SAP) and during the 1986. A direct monetary control was first placed emphasis on (1959-1986), while the era of market based controls was the second which is during (1986- date). The structural Adjustment Program (SAP) was embraced in July, 1986 as a result of the deteriorating economic conditions in the country due to crash in the international oil market. It was designed to eliminate price distortions, reduce over- dependence on crude oil exports, rationalize the role

\footnotetext{
* Corresponding author.

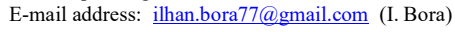


of the public sector and accelerate the growth potentials of the private sector. It is also noted that the main strategies of SAP were; the deregulation of external trade and payments arrangement, the adoption of and market- determined exchange rate, substantial reduction in complex price and more reliance on market forces as a major determinant of economic activity (CBN, 2006; Soyinbo, 2001; Ekezie, 1997).

Private sector investment which has been one of the most important factors on this study entails that any economic activities involving the provision and linking of resources to produce goods and services could lead to more output growth and greater economic development. However, the private investment and public investments are economic activities that are possible complementary that hitch better resources for increasing gross domestic product (GDP). It also offers evidence that explains that absence of public investment could limit private investment and internment the growth of GDP in the area of euro. Another challenge can be the global environmental collapse (Sanchez, 2013). Active fiscal policy increases output in public sector investment in most cases "crowds in" private investment in advanced economies in both the short-term and long-term basis (Dreger \& Reimers 2016, Abiad et al., 2015; Ajakaiye, 2001)

Sunakawa (2015), on the approach of sustainable plan, expresses that monetary policy plan (central bank) is either credible (sustainable) or is not. Although, in the language of pseudo/slack commitment, a policy plan may be reliable with some chance. Alexander (1995) stated that in the mid-70s, it became progressively challenging to achieve the goals of monetary policy because aggregates monetary, rate of GDP growth, inflation rate and balance of payments position moved in Objectionable directions. Also, during the period of oil boom, the prompt monetization of foreign exchange earnings brought about massive government spending which immensely contribute to instability in monetary, therefore, flocking out the investment in private sector and this had adverse implications for monetary management. With the monetary policy developments introduced at the primary period of SAP, some of the complications of monetary management have continued. The core constraints continue to be the ineffective control structure and the uncertainty produced by fiscal operations (Nemedia, 2006; Odozi, 1993; Koijen \& Yogo, 2019). However, over the years, the central bank of Nigeria $(\mathrm{CBN})$ has acknowledged that attaining stable prices that would encourage private sector (Otiti, 2007; Ariyo, 1998). In short term, interest rate is the ultimate aim of the new currency through stability around an operating target, to induce private sector investment and the interest rate is determined and operated by the CBN in the economy.

Nigeria over the years has been characterized by a mono-cultural economy that is given her: over dependence on a particular commodity energy (oil) sector, a growing dominance in the public sector and a quest of a highly dependent on import for industrial strategy. On these regards, the policy was justified at the beginning, the progress based on expansionary public expenditure, reliance on the export of a few primary commodities and import-substitution industrialization is neither sustainable nor efficient (De Koker, 2013). Furthermore, evidence was seen on several indices such as low industrial base with decreasing industrial output and capacity utilization, weak per capita GDP, weak growth rate, decline in the state of infrastructural and social amenities as well as high level of unemployment and low productivity in the real sector (Nnanna, 2004; Anyanwu \& Oaikhenan, 1995; Jorgenson, 1971).

Akomolafe et al. (2015) opine that the gap that exist in the literature on the dynamics of private and monetary policy suggests the need for research that will decompose and supportive in private establishment. In that the descent to such unenviable position can be ascribed to sharp depreciation of the foreign exchange value of the Naira, frequent changes in monetary policy formulation which has affected its effectiveness, lack of enabling environment financial market and continued heavy dependence on government revenue and exports. All these have contributed greatly in affecting the interest rate which eventually affects private-led investment in Nigeria. Therefore, for a country like Nigeria where the private sector is more of informal activities that are generally invisible to the regulatory system, the policy challenge translates directly to the task of the formalization of the informal activities. 
According to the above highlighted premise, the current study investigates the relationship that exists among the private investment, monetary policy and some other related variables which comprises of the broad money supply as an aspect of monetary policy, interest rate, exchange rate as well as the role of inflation in a bid to arm policymakers and government officials with ample information to adequately construct timely and robust policy framework.

The remainder of this study follows with review of related studies in section 2 . Section 3 renders the data and econometrics layout. Section 4 discusses the empirical findings while the concluding remarks are reported in section 5 .

\section{Literature Review}

In the past, the imaginary invisible hand pointed out by the classical school of thought proved incompetent in generating the necessary stimulus for the attainment of desirable conditions. It therefore became imperative for governments to initiate measures geared towards influencing the trend of economic and investment activities and the behavior of target variables. Government employed various types of policies to influence or achieve economic objectives. One of such policies available to the government is the monetary policy (Inoue \& Rossi, 2019; Clark, 2017; Ojo \& Obaseki 1998; Obaseki, 2000; Kolodko, 1999). Fasanya et al. (2013) express that monetary instruments are used to promote the social welfare. In addition, Imoughele and Ismaila (2014) opine that more monetary instruments should be introduced. The monetary policy instruments can be classified into two main classes: Quantitative and Qualitative instruments. The quantitative instruments are used in controlling money supply throughout the economy. These instruments operate on cost and availability of credit.

Sheedy (2017) examined the challenges in developing rules for conventional monetary policy suitable for post crises world. His argument was that unconventional monetary policy instrument had been used as a poor substitute to the conservative interest-rate policy in alleviating the economy and in protecting monetary policy from political densities. Nwosa and Saibu (2012) examined the transmission channels of monetary policy instincts on sectoral output growth in Nigeria from 1986 to 2009. He used quarterly data in the study, VAR and granger causality method were used for the analysis and results. The outcome revealed that the best channel for the transmission of monetary policy was associated with manufacturing segments and agriculture. It was noted that the researches done previously dealt with monetary policy and private sector investment separately but they were not in any way linked in a dynamic frame work. Some studies like Onouorah et al. (2011) concentrated on how various monetary and macroeconomic components dominated the private investment in their studies in Nigeria with a conclusion that money supply had a negative impact on private investment.

Hassan (2015) on his own part studied the effect of monetary policy on private capital formation in Nigeria. The dominant emphasis of his study was to check out if monetary policy in Nigeria had brought about substantial capital for private investment that limbs economic growth. Secondary data was used in the study and obtained from Statistical Bulletin of Central Bank of Nigeria through the period of 19862013. The study disclosed that domestic credit from financial institutions to the private sector had made its own input to growth of Private Investment in the economy. Kamaan and Nyamongo (2014) also opined in their study that quantitative measures could determine the effect of monetary policy on economic growth.

There is quite a sizeable literature on the underlying economic benefit of private investment and monetary policy which contribute to the this literature by bringing the uniqueness of the study, however, several authors for instance, have their own views that corruption is the primary factor that weakens the structures of private investment and it raises the cost of operation in the industry, which creates uncertainty and thereby deterring investment in private sector (Bräuning \& Ivashina, 2019; Taddese Lemma \& Negash, 2013; Wang \& You, 2012; Wei, 1997; Shleifer \& Vishny, 1993). 


\section{Data and Methodology}

This paper evaluates the dynamics of monetary policies and private sector investment. Several analysis were conducted in other studies to assess the relationship between private investment (LnPinv) and some variables including interest rate $(\operatorname{LIN} R)$, exchange rate $(\operatorname{LnEXR})$, broad money supply $(\operatorname{LnM} 2)$ and rate of inflation $(L n I N F)$. To achieve these objectives some techniques such as: Autoregressive Distributive lag (ARDL) bounds testing were used, for cointegration and the long run relationship between the variables under reviews. However, this study setoff with, the stationarity test to ascertain the stationarity of the variables through the Zivot and Andrew (2002) unit root test that accounts for single structural break:

According to Zivot and Andrew (2002) unit root test is expressed as:

$$
\begin{aligned}
& \Delta X_{t}=\phi_{1}+\phi_{2} t+\theta X_{t-1}+\lambda D U_{t}+\sum_{i=0}^{k} \gamma_{i} \Delta X_{t-i}+\varepsilon_{t} \\
& \Delta X_{t}=\phi_{1}+\phi_{2} t+\theta X_{t-1}+\phi D T_{t}+\sum_{i=0}^{k} \gamma_{i} \Delta X_{t-i}+\varepsilon_{t} \\
& \Delta X_{t}=\phi_{1}+\phi_{2} t+\theta X_{t-1}+\lambda D U_{t}+\phi D T_{t}+\sum_{i=0}^{k} \gamma_{i} \Delta X_{t-i}+\varepsilon_{t}
\end{aligned}
$$

\subsection{Model Specification}

The functional form for this study after the studies of Atsushi and Barbara (2019) and Berger and Bouwman (2017) on the relationship between the variables is rendered below as follows,

$$
\operatorname{LnPSI}_{t}=\beta_{0}+\beta_{1} \operatorname{LnINR}_{t}+\beta_{2} \operatorname{LnEXR}_{t}+\beta_{3} \operatorname{LnM}_{t}+\beta_{4} \operatorname{LnINF}_{t}+\varepsilon_{t}
$$

where: LnPinv is private investment, $\operatorname{LnEXR}$ is exchange rate, $\operatorname{LnINR}$ is Interest rate and $\operatorname{LnM} 2$ is broad money supply, while $L n I N F$ is inflation rate and $\varepsilon_{\mathrm{t}}$ is the stochastic term. Based on economic intuition and theory it makes sense to expect $\beta_{1}$ to be positively related to private sector investment, $\beta_{2}$ and $\beta_{3}$ to be also positively related to private sector investment while $\beta_{4}$ is expected to be negatively related to private sector investment.

\section{Result and Discussion}

In time series econometrics it is necessary to show the characterization around the dataset. The result reveals major economic and political regimes around the study area under consideration. For instance, we observe that Private investment (LnPinv) in Nigeria is on a persistent rise since 1995. The constant depreciation of the Naira exchange rate $(\operatorname{LnEXR})$ as compared with the currencies of other major trading partners, meant that more resource would be required to increase domestic output. Also, it is generally perceived that interest rate ( $L I I N R)$ plays a crucial role in the transmission of monetary policy and private sector investments. Thus, it is expected that a low positive real interest rate will engender capital accumulation which, if adequately invested would result to development in the economy. However, the effectiveness of monetary policy in regulating the money supply (LnM2) over the years in Nigeria has depended to a large extent on government spending and fiscal deficit. It is acknowledged that non-monetary or cost-push factors have been present in the recent Nigerian inflation ( $L I N F$ ) experience and, therefore the relationship between money supply movements and the price level had not been on a oneon- one basis. However, the association between the two has been quite remarkable. 
Table 1

Zivot-Andrews Unitroot test under single Structural break

\begin{tabular}{lccc}
\hline & $\begin{array}{c}\text { Statistics At (Level) } \\
\text { Test Statistic }\end{array}$ & $\begin{array}{c}\text { Statistics At (First Difference) } \\
\text { Test Stat }\end{array}$ & Order of integration \\
\hline LnPinv & -5.9766 & $-5.6639^{*}$ & $\mathrm{I}(0)$ \\
Time Break & 2010 & 1989 & \\
Lag Length & 1 & 1 & $\mathrm{I}(1)$ \\
LnEXR & -3.4753 & $-5.8914^{*}$ & \\
Time Break & 1999 & 1988 & \\
Lag Length & 1 & 1 & $\mathrm{I}(1)$ \\
LnINR & -4.9977 & $-7.5584^{*}$ & \\
Time Break & 1994 & 1994 & $\mathrm{I}(1)$ \\
Lag Length & 1 & 1 & \\
LnM2 & -4.1599 & -4.2394 & $\mathrm{I}(0)$ \\
Time Break & 2007 & 2008 & 1 \\
Lag Length & 1 & $-7.3778^{*}$ & \\
LnINF & -6.3226 & 1996 & 1 \\
Time Break & 1997 & 1 & \\
Lag Length & 1 & &
\end{tabular}

For the avoidance of spurious regression, the time series data is expected to be stationary for result soundness to hold. According to Murthy and Okunade (2016), using the conventional unit root test techniques such as ADF and PP unit root test in the case of null hypothesis being rejected it may be biased, due to permanent change in data. In this regards the Zivot and Andrew (2002) unit root test for stationarity is used to check the stationarity behavior of the time series, thereby accommodating structural break. Table 1 shows the result of Zivot and Andrew (2002) unit root test with both trend and constant terms and also uses the SIC for the optimal lag order. The result shows that LnEXR, LnINR, LnM 2 and LnINF are integrated of order one, $I(1)$. This implies that the variables are stationary at first difference. On other hand, LnPinv and $L n I N F$ are stationary at level (i.e. $I(0))$.

Table 2

Bounds Test for Co-integration

\begin{tabular}{cccc}
\hline F-Statistics & Lower bound & Upper bound & Conclusion \\
\hline 7.291644 & $3.74^{*}$ & $5.06^{*}$ & There is Cointegration \\
\hline Source: Authors Computation. Note: ${ }^{*}$ indicates 1 percent level of significance.
\end{tabular}

Since the variables are in mixed order of integration, $I(0)$ and $I(1)$, the ARDL bounds test of cointegration was used. The null hypothesis of the test is "No cointegration" which can be rejected when the F-statistic is greater than the critical value of the upper bound. The result presented in Table 2 indicates that the Fstatistic is 7.291644 and greater than the critical value of the upper bound (5.06). Therefore, the null hypothesis is rejected. This implies that there is cointegration meaning, there is long-run relationship between the variables.

Table 3

ARDL model for both short and long run model

\begin{tabular}{|c|c|c|c|c|c|c|}
\hline \multicolumn{2}{|r|}{ Short run } & \multicolumn{5}{|c|}{ Long run } \\
\hline Variable & Coefficient. & T-statistic & Prob. & Coefficient & T-statistic & Prob. \\
\hline LnPinv & 0.51488 & 3.1819 & 0.0052 & & & \\
\hline $\operatorname{LnINR}$ & 0.02934 & 2.0707 & 0.0530 & 0.04732 & 3.7935 & 0.0013 \\
\hline LnEXR & -0.25387 & -2.0026 & 0.0605 & -0.42975 & -5.4203 & 0.0000 \\
\hline $\operatorname{LnM} 2$ & 0.75534 & 1.8881 & 0.0752 & 0.83008 & 5.6075 & 0.0000 \\
\hline LnINF & 0.00304 & 1.3173 & 0.2043 & 0.00247 & 1.3324 & 0.1993 \\
\hline Diagnostic & Test & & & CONT -2.04743 & -1.12056 & 0.2717 \\
\hline R-Square & 0.99759 & & & -1.22991 & 0.00 & \\
\hline Adj R-Sq & 0.99453 & & & & & \\
\hline DW & 2.1 & & & & & \\
\hline
\end{tabular}


Table 3 shows the result for the short and long run relationship between the variables, the coefficient LnPinv seems to be positive, and the coefficient of Interest Rate (LnINR) is 0.02 in the short run and 0.04 in the long run with a t-statistic results of 2.07 and 3.79, respectively. The coefficient of the Exchange Rate $(\operatorname{LnEXR})$ seems negative both in short run and long run but the probability of the long run is stationary at $1 \%$ level shows a good change in the long run. The coefficient of money supply (LnM2) is positive both in short and long run with probability level of 0.0000 in long run. The coefficient is thus statistically significant at the $1 \%$ level. This implies that the money supply is an important determinant of the Monetary Policy during this period. On the other hand, the coefficient of inflation (LnINF) is positive as well but not stationary both in short run and long run which shows that an increase in Inflation Rate, is expected to affect the Private Sector led investment in Nigeria. The results show that the model seems to have a reasonable fit. The coefficient of the adjusted $\mathrm{R}^{2}$, indicates that it has 0.99 that is about $99 \%$ of the model explains the rate of private sector investment in Nigeria. The researchers however also employ other econometric analysis which helps in reducing the error and seeing the long run relationships among variables. However, the speed of adjustment through the error correction model (ECM) which is -1.22991 shows that it will take less than 1.2 year in other to correct the error that may occur along the line. Consequently, Table 3 shows the presence of cointegration and long run relationship in the variables using the bound test. As mentioned earlier, the coefficients of all the independent variables are positive with the exception of inflation confirm the a priori expectations. The positive sign indicates a positive relationship of the relevant variables with the private sector investment. This is an indication that the variables perform in line with the economic theory. The study however, shows that money supply, interest rate and exchange rate are strong determinate of private investment, indicating a positive relationship that exist between the variables and private investment in Nigeria during this period under study, however, this is in conformity with the aim of the study as against the findings of Onouorah et al. (2011) who draw his conclusion that money supply has no significant impact on the level of price of investment in Nigeria.

\section{Conclusion and Policy implication}

This study has attempted to ascertain the dynamics of monetary policy in regards to private sector investment in Nigeria. However, it is quite obvious to note that this particular topic has never been executed in this case study using this model, accounting for breaks, given more robust estimation. Therefore, the overall performance of private sector investment in the Nigerian economy has been far from being satisfactory in spite of efforts made by various governments. The under developed nature of the primary and secondary sectors of the economy were due to the poor implementation of macroeconomic growth variables. Over-dependence on one sector of the economy (oil) is among other things. This has held back economic progress and social wellbeing for several years. Therefore, there is a need to articulate effective policies that will improve national income and private sector investment in productive activities. It embraced the approach by the monetarist based on its relevance and effectiveness for the case at hand. Results from the critical analysis and various test of econometrics have concluded that money supply had a significant impact on the private sector investment in Nigeria. Implication of the result is that, the emphasis by the monetarist on the relative effectiveness of monetary policy in controlling private sector investment could be the best policy for the case of Nigerian economy. Other policy implication and recommendation is the need to lay down a frame work to regulate the level of inflation since it has yielded results in other countries like Kenya and China. Even though there is a negligence in the hands of government in curtailing inflation, therefore productive industry and other sectors like agricultural sector need to be improved through appropriate fiscal policies. Finally, the central bank of Nigeria needs to continue focusing on controlling the growth of money shock through a restrictive monetary policy since it has been observed that more emphasis is laid on a single sector. Furthermore, proper channeling of financial resources to the private sector should be an important priority of the government in order to eliminate the leakage from the financial system to public enterprises, and private firms, thereby reducing 
public ownership and promoting entry and competition will increase the volume and effectiveness of financial freedom.

\section{References}

Abiad, M. A., Furceri, D., \& Topalova, P. (2015). The macroeconomic effects of public investment: evidence from advanced economies (No. 15-95). International Monetary Fund.

Ajakaiye, D.O. (2001). Economic Development in Nigeria. A review of Recent Experiences in CBN, Growing the Nigerian Economy, Abuja, Nigeria. CBN Annual Monetary, 37(12).

Ajayi, S. I. (1978). Money in a developing economy: A portfolio approach to money supply determination in Nigeria. Ibadan University Press.

Akomolafe, K. J., Bosede, O., Emmanuel, O., \& Mark, A. (2015). Public debt and private investment in Nigeria. American Journal of Economics, 5(5), 501-507.

Alexander, E. W. (1995). The study on adoption of indirect mechanisms of monetary policy. IMF staff occasional paper, 32(126), 36.

Anyanwu, J. C., \& Oaikhenan, H. E. (1995). Modern macroeconomics: Theory and applications in Nigeria. Department of Economics \& Statistics, University of Benin.

Ariyo, A. (1998). Investment and Nigeria's economic growth. In Investment in the Growth Process: Proceedings of the Nigerian Economic Society Conference, Ibadan, Nigeria (pp. 329-349).

Berger, A. N., \& Bouwman, C. H. (2017). Bank liquidity creation, monetary policy, and financial crises. Journal of Financial Stability, 30, 139-155.

Bräuning, F., \& Ivashina, V. (2019). US monetary policy and emerging market credit cycles. Journal of Monetary Economics.

Brauning, F., \& Ivashina, V. (2017). Monetary policy and global banking (No. w23316). National Bureau of Economic Research.

CBN (1992). The evolution and performance of monetary policy in Nigeria during 1980's. CBN Bullion.

Clark, J. M. (1917). Business acceleration and the law of demand: A technical factor in economic cycles. Journal of Political Economy, 25(3), 217-235.

De Koker, L., \& Jentzsch, N. (2013). Financial inclusion and financial integrity: Aligned incentives? World development, 44, 267-280.

Dreger, C., \& Reimers, H. E. (2016). Does public investment stimulate private investment? Evidence for the euro area. Economic Modelling, 58, 154-158.

Ekezie, E. S. (1997). The elements of banking. Onitsha: Africana-Feb Publishers Ltd. Federal Republic of Nigeria Official Gazette, 26.

Fasanya, I. O., Onakoya, A. B., \& Agboluaje, M. A. (2013). Does monetary policy influence economic growth in Nigeria. Asian Economic and Financial Review, 3(5), 635-646.

Hassan, O. M. (2015). The impact of monetary policy on private capital formation in Nigeria. Journal of Empirical Economics, 4(3), 138-153.

Imoughele, L. E., \& Ismaila, M. (2014). Empirical Investigation of the Impact of Monetary Policy on Manufacturing Sector Performance in Nigeria (1986-2012). International Journal of Education and Research, 2(1), 1-20.

Inoue, A., \& Rossi, B. (2019). The effects of conventional and unconventional monetary policy on exchange rates. Journal of International Economics, 118, 419-447.

Jorgenson, D. W. (1971). Econometric studies of investment behavior: A survey. Journal of Economic literature, 9(4), 1111-1147

Kamaan, C. K., \& Nyamongo, E. M. (2014). The effect of monetary policy on economic growth in Kenya. International Journal of Business and Commerce, 3(8), 11-24.

Kolodko, G. W. (1999). Incomes policy, equity issues, and poverty reduction in transition economies. $\mathrm{Fi}$ nance and Development, 36(3), 32.

Taddese Lemma, T., \& Negash, M. (2013). Institutional, macroeconomic and firm-specific determinants of capital structure: The African evidence. Management Research Review, 36(11), 1081-1122. 
Murthy, V. N., \& Okunade, A. A. (2016). Determinants of US health expenditure: Evidence from autoregressive distributed lag (ARDL) approach to cointegration. Economic Modelling, 59, 67-73.

Nemedia, C. (2006). Elements of Macroeconomic Management: Monetary Policy. Journal of Empirical Economics 4(3), 138-153

Nnanna, O. J. (2004, November). Beyond bank consolidation: The impact of society. In A paper presented at the 4th Annual Monetary Policy conference of the Central Bank of Nigeria, Abuja (18th19th November).

Nwosa, P. I., \& Oseni, I. O. (2012). Monetary Policy, Exchange Rate and Inflation Rate in Nigeria: A Co-integration and Multivariate Vector Error Correction Model Approach. Research Journal of Finance and Accounting, 3(3), 62-69.

Obaseki, P. J. (2000). Globalization and the Nigerian economy. Central Bank of Nigeria Economic and Financial Review, 38(2), 17-33.

Odozi, V.A. (1993). Shows the Current Monetary and Banking Policies within Nigeria and the Projections in the Third Republic. Central Bank of Nigeria Economic and Financial Review, 30(3).

Ojo, M. O., \& Obaseki, P. J. (1998). Challenges of globalization for macroeconomic policy and management in Nigeria. CBN Economic and Financial Review, 36(4), 415-440.

Koijen, R. S., \& Yogo, M. (2019). Exchange Rates and Asset Prices in a Global Demand System. Available at SSRN 3383677.

Onouorah, A., Shaib, I. O., Oyathelemi, E., \& Friday, O. I. (2011). The impact of monetary policy on micro-economy and private investment in Nigeria. Research Journal of Finance and Accounting, 2(6), 65 .

Otiti, A. 0. (2007). Essay on Recent Issues in the Nigerian Financial System. CIBN Press Ltd, Tarton, Yaba, Lagos.

Pesaran, M. H., Shin, Y., \& Smith, R. J. (2001). Bounds analysis, testing approaches to the analysis of glassy relationships. Journal of the Applied Econometrics, 16(3), 289-326.

Sánchez, R. R. (2013). The complex political economy of natural capitalism: The case of Whole Foods, Stonyfield Farms, and Walmart. Online Journal of Communication and Media Technologies, 3(3), 178-198.

Sheedy, K. D. (2017). Conventional and unconventional monetary policy rules. Journal of Macroeconomics, 54, 127-147.

Shleifer, A., \& Vishny, R. W. (1993). Corruption. The Quarterly Journal of Economics, 108(3), 599617.

Soyinbo, A. K (2001). A review of Nigeria's privatization programme. Development Policy Centre Research Report, 23, 9.

Sunakawa, T. (2015). A quantitative analysis of optimal sustainable monetary policies. Journal of Economic Dynamics and Control, 52, 119-135.

Wang, Y., \& You, J. (2012). Corruption and firm growth: evidence from China. China Economic Review, 23(2), 415-433.

Wei, S. J. (1997). Why is corruption so much more taxing than tax? Arbitrariness kills (No. w6255). National bureau of economic research.

Zivot, E., \& Andrews, D. W. K. (2002). Further evidence on the great crash, the oil-price shock, and the unit-root hypothesis. Journal of Business \& Economic Statistics, 20(1), 25-44.

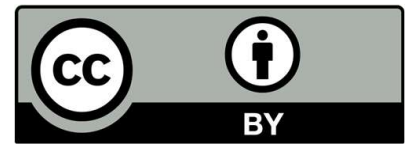

(C) 2020 by the authors; licensee Growing Science, Canada. This is an open access article distributed under the terms and conditions of the Creative Commons Attribution (CCBY) license (http://creativecommons.org/licenses/by/4.0/). 